
SHORT COMMUNICATIONS

\title{
LEPTURA AURULENTA (COLEOPTERA, CERAMBYCIDAE), A NEW RECORD OF A VERY RARE SPECIES IN RUSSIA
}

\author{
Alexander B. Ruchin ${ }^{1}$, Leonid V. Egorov ${ }^{1,2}$ \\ ${ }^{1}$ Joint Directorate of the Mordovia State Nature Reserve and National Park «Smolny», Russia \\ e-mail: sasha_ruchin@rambler.ru \\ ${ }^{2}$ Prisursky State Nature Reserve, Russia \\ e-mail:platyscelis@mail.ru
}

Received: 18.09.2017

\begin{abstract}
The paper presents data on a new record of a very rare insect, Leptura aurulenta (Coleoptera, Cerambycidae), in the Mordovia State Nature Reserve (Russia). This is a third reliable registration of this species within Russia. It expands the range of this beetle to $600 \mathrm{~km}$ to the east. We have presented an original biotope description, data on distribution and biology of $L$. aurulenta.
\end{abstract}

Key words: Coleoptera, Leptura aurulenta, Mordovia State Nature Reserve, new record

\section{Introduction}

The Mordovia State Nature Reserve is located in the Temnikov district of the Republic of Mordovia. It belongs to the Central Russian subprovince of the Eastern European province of the European broad-leaved forest region on the wooded rightbank of the River Moksha (Gribova et al., 1980). The forest-steppe naturally marks the boundary of the protected area from the south. The climate of the Mordovia Reserve is related to the Atlanticcontinental region of the temperate zone (Gafferberg, 2015). Intensive entomological studies of recent years have shown many new and interesting findings of Coleoptera species in the Mordovia Reserve area (Legalov et al., 2014; Egorov et al., 2015, 2016, 2017; Egorov \& Shapovalov, 2017; Ruchin \& Egorov, 2017; Semenov, 2017).

The family of longicorn beetles (Cerambycidae) belongs to one of the most interesting taxonomic groups of Coleoptera. In ecosystems, the species of this family participate, first of all, in the wood biodegradation (at larval stage) and pollination of flowering plants (imago). The longicorn beetles' research is also important for biodiversity study. However, some species of longicorns are very rare and listed in the Red Data Books on federal and regional level. The present report contains information about the discovery of the rarest longicorn beetle in Russia - Leptura aurulenta Fabricius, 1793 in the Mordovia State Nature Reserve.

\section{Material}

The Republic of Mordovia, Temnikov district, $17 \mathrm{~km} \mathrm{NW}$ from the city of Temnikov, Mordovia State Nature Reserve, forest square 324, 15.07.2017, 1 specimen, A.B. Ruchin (Fig. 1). The specimen was transferred to the collection of the Zoological Institute of the Russian Academy of Sciences (St. Petersburg, Russia).

\section{Description of the biotope}

The female $L$. aurulenta was caught on the western narrow clearing of forest square 324 of the Mordovia State Nature Reserve. The beetle sat on the inflorescence of a plant of the Apiaceae family. This quarter has a developed forest and meadow vegetation. In the south-western and north-western corners of this quarter there are small areas of ripening and ripe lime trees, in the stand of which occur sparsely Quercus robur L., Ulmus laevis Pall. and U. glabra Huds. The undergrowth includes Euonymus verrucosa Scop. and Padus avium Mill. The herbaceous level is formed mainly by Aegopodium podagraria L., Dryopteris filix-mas (L.) Schott, Lamium maculatum (L.) L., in damp places Urtica dioica L. and Humulus lupulus L. occur. There is a lot of leaf litter. Next to the lime (Tilia cordata Mill.) trees there is a small area of ripening oak (Quercus robur) forest with a similar species composition of the flora. It is located in the south-western part of the quarter along the southern clearing. Oak forests occupy 
small areas in the central, eastern and southeastern parts of the forest quarter (Fig. 2). The eastern half of the quarter and part of the western half are occupied by swampy alder (Alnus glutinosa) forest with Padus avium and Humulus lupulus in the undergrowth, and Glyceria maxima (C. Hartm.) Holmb., Carex acuta L., $C$. riparia Curt. and $C$. vesicaria L., Scirpus sylvaticus L., and Filipendula ulmaria (L.) Maxim. in the herb layer. Most of the western half is occupied by flood meadows situated along the River Pushta. Their species composition includes the following Gramineae species: Glyceria maxima, Phalaroides arundinaceae (L.) Rausch., Poa palustris L., P. pratensis L., Bromopsis inermis (Leyss.) Holub . Common sedges here are Carex acuta, $C$. vesicaria, $C$. riparia, $C$. vulpina $\mathrm{L}$. The forb vegetation is presented mostly by the following hygrophytes: Filipendula ulmaria, Symphytum officinale L., Lythrum salicaria L., Lysimachia vulgaris L.

\section{Distribution}

According to the latest report on longicorn beetles of Russia (Danilevsky, 2014), in Russia Leptura aurulenta is extremely rare, reliably known only from the Tellerman Forest near Voronezh; (Odoyev district, forest 3-4 km south of Odoyev) (Mamontov \& Nikitsky, 2007). The rest of the findings are either questionable or not confirmed. There are also unreliable data on this species in the westernmost region of Russia - the Kaliningrad region (Alekseev, 2007).

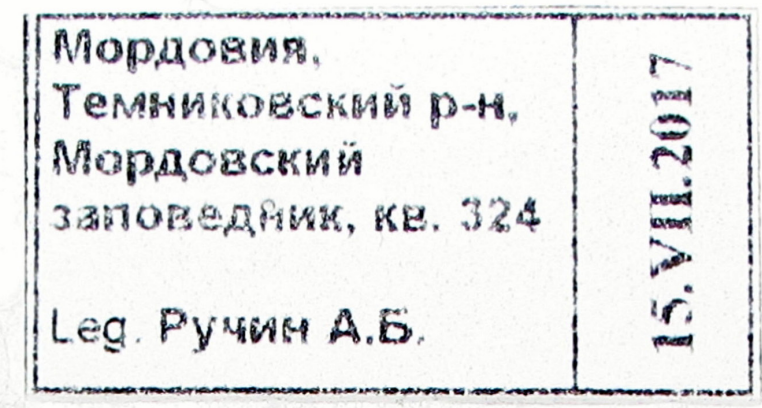

$$
\begin{aligned}
& \text { Mopgobun, Thumakol. } \\
& \text { crivipm, /7xm C. } 3 \\
& \text { 2. Temmuk ob }
\end{aligned}
$$

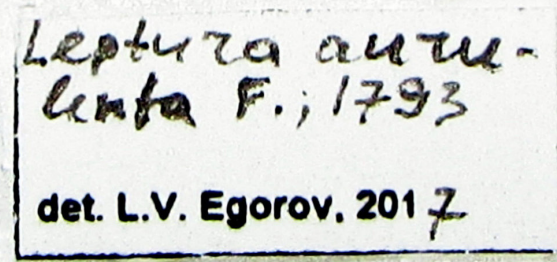

Fig. 1. Leptura aurulenta, a female and the label of the collected specimen.
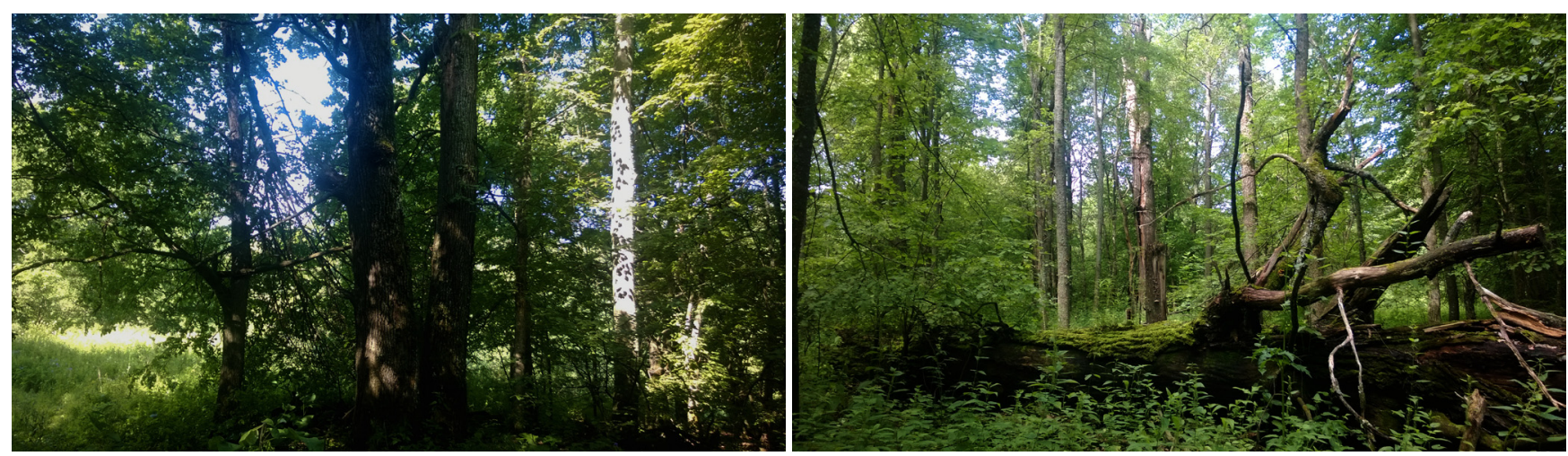

Fig. 2. Biotopes in the forest square 324 of the Mordovia State Nature Reserve (Photos: A.B. Ruchin). 
Outside Russia, Leptura aurulenta extends much wider to the west: from northern Spain and Portugal to the east across France, it lives in the south of Great Britain and Ireland, in Italy, in the north of Greece, in Bulgaria, Belgium, Romania, Hungary, Austria, Germany, Serbia, Slovakia, the European part of Turkey, it is also reliably known from Algeria (Kovács, 1993; Holzinger et al., 1999; Twinn \& Harding, 1999; Adlbauer, 2001; Martínez de Murguía et al., 2004; Pil \& Stojanović, 2007; Özdikmen, 2010; Turgut et al., 2010; Sama \& Rapuzzi, 2011; Alexander \& Anderson, 2012; Smets et al., 2013; Danilevsky, 2014; Holzinger et al., 2014; Stefanelli et al., 2014; Majzlan, 2015). Leptura aurulenta is known from central Moldova (Neculiseanu \& Baban, 2005; Chyubchik, 2010), in Ukraine in Kharkiv, Chernihiv region, in the southwest and in the Carpathians (Bartenev, 2004). The finding for Lithuania (Löbl \& Smetana, 2010) is invalid (Tamutis et al., 2011).

\section{Biology}

The females of this species are usually found on the trunks of hardwood trees (Quercus, Ulmus, Salix, Populus, Betula, Alnus, Prunus), while males often occur on flowers (Holzinger et al., 1999; Alexander \& Anderson, 2012; Giovagnoli et al., 2012; Smets et al., 2013). Larvae develop in the dry wood of old stumps and roots of the above-mentioned hardwood trees, as well as in fallen trunks and branches and in dead parts of living trees. The life cycle lasts for several years (Smets et al., 2013).

Thus, the discovery of L. aurulenta in the Mordovia State Nature Reserve is the third reliable finding of this rare beetle species in Russia. And this is the most eastern finding of L. aurulenta within its range. Due to the extreme rarity of L. aurulenta in Russia its inclusion in the Red Data Book of the Russian Federation is needed and recommended.

\section{Acknowledgments}

The authors are sincerely grateful to E.V. Vargot (Mordovia State Nature Reserve) for help in describing biotopes, M.L. Danilevsky (Moscow) for confirmation of the species definition, N.V. Borisova (Cheboksary) for sending us a photo of the beetle, V.I. Alekseev (Kaliningrad) and N.B. Nikitsky (Moscow) for information support.

\section{References}

Adlbauer K. 2001. 2. Nachtrag zur Bockkäferfauna der Steiermark unter dem Aspekt der Artenbedrohung (Coleoptera, Cerambycidae). Joannea Zoologie 3: 83-104.
Alekseev V.I. 2007. Longhorn beetles (Coleoptera: Cerambycidae) of Kaliningrad region. Acta Biologica Universitatis Daugavpiliensis 7(1): 37-62.

Alexander K.N.A., Anderson R. 2012. The beetles of decaying wood in Ireland. A provisional annotated checklist of saproxylic Coleoptera. Irish Wildlife Manuals, No. 65. Dublin: National Parks and Wildlife Service, Department of the Arts, Heritage and the Gaeltacht. $161 \mathrm{p}$.

Bartenev A.F. 2004. A review of the long-horned beetles species (Coleoptera: Cerambycidae) of the fauna of Ukraine. Kharkov Entomological Society Gazette 11(12): 24-43. [In Russian]

Löbl I., Smetana A. (Eds.). 2010. Catalogue of Palaearctic Coleoptera. Vol. 6: Chrysomeloidae. Stenstrup: Apollo Books. 924 p.

Chyubchik V.Yu. 2010. The annotated list of longicorn-beetles (Coleoptera: Cerambycidae) of Central Moldova. Russian Entomological Journal 19(2): 111-118.

Danilevsky M.L. 2014. Longicorn beetles (Coleoptera, Cerambycoidea) of Russia and adjacent countries. Part 1. Moscow: Vysshaya Shkola Konsaltinga. 518 p. [In Russian]

Gafferberg I.G. 2015. Climate of the Mordovia State Nature Reserve. 1938. Proceedings of the Mordovia State Nature Reserve 13: 5-20. [In Russian]

Egorov L.V., Ruchin A.B., Semishin G.B. 2015. Some data concerning the Coleoptera fauna of the Mordovia State Nature Reserve. Report 4. Proceedings of the Mordovia State Nature Reserve 14: 82-156. [In Russian]

Egorov L.V., Ruchin A.B., Semishin G.B. 2016. Some data concerning the Coleoptera fauna of the Mordovia State Nature Reserve. Report 5. Proceedings of the Mordovia State Nature Reserve 16: 293-364. [In Russian]

Egorov L.V., Ruchin A.B., Semishin G.B. 2017. Some data concerning the Coleoptera fauna of the Mordovia State Nature Reserve. Report 6. Proceedings of the Mordovia State Nature Reserve 18: 81-143. [In Russian]

Egorov L.V., Shapovalov A.M. 2017. On the distribution of a poorly known longicorn beetle, Phymatodes abietinus Plavilstshikov et Lurie, 1960 (Coleoptera, Cerambycidae: Cerambycinae). Entomological Review 97 (3): 353-356.

Giovagnoli G., Strocchi A., Paglialunga M. 2012. Coleoptera of the Marches Region. First contribution to the knowledge of Coleoptera fauna of the Marches. Quaderno di Studi e Notizie di Storia Naturale della Romagna 36: 159-184.

Gribova S.A., Isachenko T.I., Lavrenko E.M. (Eds.). 1980. Vegetation of the European Part of the USSR. Leningrad: Nauka. 429 p. [In Russian].

Holzinger W.E., Frieß T., Holzer E., Mehlmauer P. 2014. Xylobionte Käfer (Insecta: Coleoptera part.) in Wäldern des Biosphärenparks Wienerwald (Österreich: Niederösterreich, Wien). Wissenschaftliche Mitteilungen Niederösterreichisches Landesmuseum 25: 331-362.

Holzinger W.E., Mildner P., Rottenburg T., Wieser (Hrsg.) C. 1999. Rote Listen gefährdeter Tiere Kärntens. Naturschutz in Kärnten 15: 269-286.

Kovács T. 1993. The long-horn beetle fauna of Kisterenye and its vicinity (Coleoptera, Cerambycidae). Folia Historico Naturalia Musei Matraensis 18: 49-68. 
Legalov A.A., Egorov L.V., Ruchin A.B. 2014. First record of Mesauletobius pubescens (Kiesenwetter, 1851) (Coleoptera, Rhynchitidae) in Russia. Euroasian Entomological Journal 13(4): 400. [In Russian]

Majzlan O. 2015. Beetles (Coleoptera) of the Nature reserve Kulhán̆ near the village Zlatníky (Duchonka). Entomofauna Carpathica 27(2): 19-40.

Mamontov S.N., Nikitsky N.B. 2007. To the knowledge of xylophilic Coleoptera species in forests of the Tula region. In: Collection of scientific works of teachers and post-graduate students of Tula State Pedagogical University. Tula. P. 95-97. [In Russian]

Martínez de Murguía L., Lapaza J., Salaberria E., Méndez M., Molino-Olmedo F. 2004. Saproxylic coleoptera (Insecta: Coleoptera) of a regenerating acidophilous beech-forest in the north of the Iberian Peninsula. $M u$ nibe (Ciencias Naturales-Natur Zientziak) 55: 167-182.

Neculiseanu Z., Baban E. 2005. Fauna cerambicidelor (Coleoptera: Cerambycidae) din Republica Moldova. Analele stiintifice ale USM. Seria «Stiinte chimicobiologice». 2005: 199-202.

Özdikmen H. 2010. Longicorn beetles fauna of European Turkey: A revision to the list of Özdikmen, 2008 (Coleoptera: Cerambycidae). Munis Entomology \& Zoology 5(Suppl.): 924-944.

Pil N., Stojanović D. 2007. Second contribution to knowledge of longhorn beetles (Coleoptera: Cerambycidae) from Mt. Fruška Gora. Acta Entomologica Serbica 12(1): 39-44.
Ruchin A.B., Egorov L.V. 2017. New and interesting species of Coleoptera in the Republic of Mordovia. Eversmannia 51-52: 21-26.

Semenov V.B. 2017. Some data concerning the rove beetles (Coleoptera, Staphylinidae) of the Mordovia Reserve. Proceedings of the Mordovia State Nature Reserve 18: 190-205. [In Russian].

Sama G., Rapuzzi P. 2011. Una nuova Checklist dei Cerambycidae d'Italia (Insecta Coleoptera Cerambycidae). Quaderno di Studi e Notizie di Storia Naturale della Romagna 32: 121-164.

Smets K., Drumont A., Crevecoeur L. 2013. Note on the distribution of Leptura aurulenta Fabricius, 1792 in Belgium (Coleoptera: Cerambycidae: Lepturinae). Bulletin de la Société royale belge d'Entomologie 149: 139-149.

Stefanelli S., Rocca F.D., Bogliani G. 2014. Saproxylic beetles of the Po plain woodlands, Italy. Biodiversity Data Journal 2: e1106. DOI: 10.3897/BDJ.2.e1106.

Tamutis V., Tamute B., Ferenca R. 2011. A catalogue of Lithuanian beetles (Insecta, Coleoptera). ZooKeys 121: 1-494. DOI: 10.3897/zookeys.121.732

Turgut S., Özdikmen H., Cebeci, H. 2010. Oxymirus cursor and Leptura aurulenta (Coleoptera: Cerambycidae): first records for Turkey. Florida Entomologist 93(4): 516-518. DOI: 10.1653/024.093.0407

Twinn P.F.G., Harding P.T. 1999. Provisional atlas of the longhorn beetles (Coleoptera, Cerambycidae) of Britain. Huntingdon: Biological Records Centre. 96 p.

\title{
НОВАЯ НАХОДКА ОЧЕНЬ РЕДКОГО ДЛЯ РОССИИ ВИДА LEPTURA AURULENTA (COLEOPTERA, CERAMBYCIDAE)
}

\author{
А. Б. Ручин ${ }^{1}$, Л. В. Егоров ${ }^{1,2}$ \\ ${ }^{1}$ Объединенная дирекиия Мордовского государственного природного заповедника имени П.Г. Смидовича \\ и наиионального парка «Смольный», Россия \\ e-mail:sasha_ruchin@rambler.ru \\ ${ }^{2}$ Государственный природный заповедник «Присурский», Россия \\ e-mail:platyscelis@mail.ru
}

\begin{abstract}
Приведены сведения о находке в Мордовском заповеднике (Республика Мордовия) крайне редкого вида усачей Leptura aurulenta (Coleoptera, Cerambycidae). Это третья достоверная регистрация вида в пределах России. Она расширяет ареал вида на 600 км на восток. Даются оригинальное описание биотопа, сведения о распространении и биологии вида.
\end{abstract}

Ключевые слова: Coleoptera, Leptura aurulenta, Мордовский государственный заповедник, новое местонахождение 